\title{
Phytoecdysteroids as modulators of the Toxoplasma gondii growth rate in human and mouse cells
}

Katarzyna Dzitko ${ }^{1 *}$, Marcin Mikołaj Grzybowski, Jakub Pawełczyk², Bożena Dziadek', Justyna Gatkowska', Paweł Stączek ${ }^{3}$ and Henryka Długońska ${ }^{1}$

\begin{abstract}
Background: Searching for new effective drugs against human and animal toxoplasmosis we decided to test the anti-Toxoplasma potential of phytoecdysteroids (a-ecdysone and 20-hydroxyecdysone) characterized by the pleiotropic activity on mammalian organisms including the enhancement of host's anti-parasitic defence. This objective was accomplished by the in vitro evaluation of T. gondii growth in phytoecdysteroid-treated immunocompetent cells of selected hosts: humans and two strains of inbred mice with genetically determined different susceptibility to toxoplasmosis.

Methods: Peripheral mononuclear blood cells were isolated from Toxoplasma-positive and Toxoplasma-negative women $(N=43)$ and men $(N=21)$. Non-infected mice $(C 57 B L / 6, N=10$ and BALB/C, $N=14)$ and mice $(B A L B / C, N=10)$ challenged intraperitoneally with 5 tissue cysts of the T. gondii DX strain were also used in this study as a source of splenocytes. The effects of phytoecdysteroids on the viability of human PBMC and mouse splenocytes were evaluated using the MTT assay. The influence of phytoecdysteroids on PBMCs, splenocytes and T. gondii proliferation was measured using radioactivity tests (the level of $3[\mathrm{H}]$ uracil incorporation by toxoplasms or $3[\mathrm{H}]$ thymidine by PBMCs and splenocytes), which was confirmed by quantitative Real-Time PCR. Statistical analysis was performed using SigmaStat 3.5 (Systat Software GmbH). The best-fit IC50 curves were plotted using GraphPad Prism 6.0 (GraphPad Software, Inc.).
\end{abstract}

Results: Our results showed that phytoecdysteroids promote the multiplication of Toxoplasma in cultures of human or murine immune cells, in contrast to another apicomplexan parasite, Babesia gibsoni. Additionally, the tested phytoecdysteroids did not stimulate the in vitro secretion of the essential protective cytokines (IFN-, IL-2 and IL-10), neither by human nor by murine immune cells involved in an effective intracellular killing of the parasite.

Conclusions: Judging by the effect of phytoecdysteroids on the T. gondii proliferation, demonstrated for the first time in this study, it seems that these compounds should not be taken into consideration as potential medications to treat toxoplasmosis. Phytoecdysteroids included in the food are most likely not harmful for human or animal health but certain nutrients containing ecdysteroids at high concentrations could promote $T$. gondii proliferation in chronically infected and immunocompromised individuals. In order to assess the real impact of ecdysteroids on the course of natural T. gondii invasion, in vivo research should be undertaken because it cannot be ruled out that the in vivo effect will be different than the in vitro one. However, taking into account the possible stimulating effect of ecdysteroids on some opportunistic parasites (such as Toxoplasma or Strongyloides) further studies are necessary and should focus on the mechanisms of their action, which directly or indirectly enhance the parasite growth. Since ecdysteroids are considered as potential drugs, it is essential to determine their effect on various parasitic pathogens, which may infect the host at the same time, especially in immunocompromised individuals.

\footnotetext{
* Correspondence: dzika@biol.uni.lodz.pl

${ }^{1}$ Department of Immunoparasitology, Faculty of Biology and Environmental

Protection, University of Łódź, Banacha 12/16, 90-237 Łódź, Poland

Full list of author information is available at the end of the article
} 


\section{Background}

Toxoplasma gondii is a cosmopolitan intracellular protozoan that causes toxoplasmosis in birds, mammals and humans. Statistical data concerning the prevalence of toxoplasmosis indicated that at least one-third of human population has had contact with this parasite. The high prevalence of $T$. gondii infection (e.g., in some parts of Europe 58-90 \%) is related to sex, age, culinary habits, personal hygiene, condition of the immune system and dysfunctions of the endocrinal network [1-3]. Despite the significant progress in the research on the biology of $T$. gondii invasion, the proteome of this protozoan and the immunity it induces, no preventive vaccines for humans have been developed yet.

T. gondii infection leads to congenital or acquired postnatal toxoplasmosis characterized by diverse forms and symptoms. In immunocompetent humans, the infection is usually asymptomatic as the primary immunological response quickly limits the parasite replication and its spreading. Thus, symptomatic toxoplasmosis occurs infrequently. Quickly replicating tachyzoites are converted into bradyzoites and become enclosed in tissue cysts, which are a sign of chronic toxoplasmosis [4]. Recent studies demonstrated that a long-term presence of the parasite is not neutral to the host. It is increasingly often postulated that there is a causal connection between the $T$. gondii carriage and the increased risk of neurologic diseases, such as schizophrenia [5], Parkinson's disease [6] or epilepsy [7]. Moreover, a very significant clinical problem is posed by congenital toxoplasmosis, resulting from the primary infection of a mother during pregnancy and transmission of the parasite to a fetus with an immature immune system. In chronically infected women there is usually no placental parasite transmission to a fetus, thus, an especially interesting group for clinicians and immunoparasitologists are seronegative women at a child-bearing age, in whom the development of a primary infection may cause a miscarriage or congenital defects of the offspring, such as hydrocephaly or microcephaly, chorioretinitis and intracranial calcification, which constitute the so-called "Sabin-Feldman triad". This parasite may also cause serious medical disorders in humans related to the unchecked proliferation of the protozoan in immunocompromised patients. A weakened immune system is not able to inhibit the parasite replication during the reactivation of a latent infection or the reinvasion by a new strain of a different genotype. Uncontrolled $T$. gondii invasion in such cases can become a direct cause of death $[8,9]$.

In the treatment of most clinical forms of toxoplasmosis, the antagonists of folic acid are used: pyrimethamine in combination with sulfadiazine [10]. Although such therapy is often effective, it may cause multiple side effects, such as bone marrow suppression, which leads to the necessity of concurrent administration of folic acid [11]. Additionally, because of the frequent intolerance to sulfadiazine, it is often necessary to administer other medications, e.g., clindamycin or co-trimoxazole. Numerous drugs used in the treatment of toxoplasmosis cause many side effects including allergic reactions, leukopenia, anemia, thrombocytopenia, cardiac dysrhythmia, as well as digestive tract disorders and skin pigmentation disorders. Hence, searching for less toxic drugs that will effectively act against all life-stages of the parasite is crucial for the improvement of $T$. gondii infections treatment.

As current chemotherapy is still not satisfactory, many attempts are made at developing specific immunoprophylaxis (a vaccine that will induce strong protective immunity against toxoplasmosis) [12-14] and obtaining not only new drugs [15-18] but also alternative therapeutical preparations derived from plants $[19,20]$. Such alternative methods motivate scientists to search for new strategies to fight toxoplasmosis $[3,21]$. Because of the pleiotropic activity of phytoecdysteroids on mammalian organisms (including humans), they gain interest as agents that potentially enhance the antibacterial, antifungal and antiparasitic activity of host cells. Such studies are still scarce, however, the obtained results are very promising and give hope for future application of ecdysteroids in the chemotherapy of parasitoses. It has been shown that certain plant extracts are able to suppress the growth of some Apicomplexa protozoans. For instance, the infusion of Artemisia annua, rich in artemisinin and its derivatives, inhibited the proliferation of $T$. gondii and Plasmodium falciparum [22]. Interestingly, the extracts of Sophora flavescens and Zingiber officinale proved to be highly selective against the RH strain of $T$. gondii [23]. These exemplary results indicate that plants might be a valuable source of drugs against parasitic diseases, including toxoplasmosis. Novel plant-derived compounds might be used to replace or complement currently used chemotherapeutic agents. Furthermore, 20-hydroxyecdysone obtained from the plant Arcangelisia flava demonstrated an inhibitory effect on the protozoan parasite Babesia gibsoni [24], the etiological agent of babesiosis in dogs, which, like $T$. gondii, belongs to the Apicomplexa phylum. It raises a question whether 20-hydroxyecdysone might have a similar effect on $T$. gondii.

\section{Methods}

\section{Ethical approval}

All experimental procedures on female (10-12 weeks old) inbred $\mathrm{C} 57 \mathrm{BL} / 6\left(\mathrm{H}-2^{\mathrm{b}}\right)$ and BALB/C $\left(\mathrm{H}-2^{\mathrm{d}}\right)$ mice kept under standard laboratory conditions, were conducted according to the guidelines of the Local Ethics Commission for Experiments on Animals in Lodz (licence number 39/ $Ł B 475 / 2009)$. Mice were used for the propagation of 
Toxoplasma tachyzoites and to obtain splenocytes as host cells for in vitro parasite proliferation tests.

\section{DX and RH Toxoplasma gondii cultivation}

$T$. gondii tissue cysts of the low virulence DX strain (intraspecies type II) were used for mice challenge. DX strain was maintained in C57BL/6 mice by the passage of five brain cysts administered intraperitoneally every 2 months.

The tachyzoites of the $T$. gondii $\mathrm{RH}$ strain - intraspecies type I (ATCC ${ }^{\circ}$ Number $50174^{\text {Tn }}$ ) were maintained through passages on female $\mathrm{C} 57 \mathrm{BL} / 6$ and $\mathrm{BALB} / \mathrm{c}$ mice with genetically determined high and low susceptibility (respectively) to $T$. gondii infection. The tachyzoites washed out from the peritoneal cavity were expanded in vitro on the $\mathrm{L} 929$ cell line (ATTC ${ }^{\bullet}$ Catalog No. CCL-1, mouse fibroblasts) for one infection cycle. Co-cultures of tachyzoites and host cells were cultivated in Iscove's Modified Dulbecco's Medium (IMDM), supplemented with $2 \mathrm{mM}$ L-glutamine, $100 \mathrm{U} / \mathrm{mL}$ penicillin, $100 \mu \mathrm{g} / \mathrm{mL}$ streptomycin, $5 \times 10^{-5} \mathrm{M} \beta$-mercaptoethanol and $5 \%$ Fetal Bovine Serum (FBS). All commercial reagents were purchased from Sigma-Aldrich (Poland). Extracellular parasites were pelleted from the culture supernatant of the host cells, passed through a $5 \mu \mathrm{m}$ pore filter (Sartorius, Poland) and centrifuged $\left(720 \times g, 15 \mathrm{~min}, 24^{\circ} \mathrm{C}\right)$.

\section{Blood collection, processing and human peripheral blood mononuclear cells isolation}

Clinical and serological analyses were performed on a group of 43 women and 21 men in the age range of 20-67 years (mean value 31.6 years; median 28 ). Only those patients who voluntarily signed a written agreement were involved in the project. The study was approved by the Local Committee of Ethics in Science (licence number $11 / 10 / 2005)$ and conducted in accordance with the Helsinki Declaration.

Clinical specimens for the study were collected from each patient and consisted of serum samples (used to determine the presence of the anti-Toxoplasma IgG antibody) and peripheral blood samples stabilized with EDTA (as a source of peripheral blood mononuclear cells - PBMCs). PBMCs were isolated from the blood samples using a Leucosept-Tube with Ficoll-Paque Plus ${ }^{\circ}$ (Greiner Bio-One, Germany) according to the manufacturer's instructions. The final number of PBMCs was adjusted to $2.5 \times 10^{6}$ cells $/ \mathrm{mL}$ and they were used as host cells for T. gondii in vitro proliferation tests.

\section{Mouse splenocytes and brains isolation}

Non-infected C57BL/6 mice $(N=10), B A L B / c$ mice $(N=14)$ and the ones challenged intraperitoneally with 5 tissue cysts of the T. gondii DX strain (non-lethal dose) BALB/c mice $(N=10)$ were also used in this study. Four weeks after the challenge and directly prior to the experiment the animals were euthanized and the spleens and brains were isolated.

The brain of each mouse was homogenized by 10 passages through each of 19-, 20- and 21-gauge needles and finally suspended in $2 \mathrm{~mL}$ of PBS. The mean brain cyst load was determined by counting $25 \mu \mathrm{L}$ samples of the homogenate under an Olympus inverted optical microscope at $200 \times$ magnification. All samples were counted in duplicate. Challenged mice marked as Toxoplasma-

Table 1 Metabolic activity of human PBMCs

\begin{tabular}{|c|c|c|c|c|c|}
\hline & & \multicolumn{4}{|c|}{ Metabolic activity [\%] of human PBMCs } \\
\hline & & $24 \mathrm{~h}$ & $48 \mathrm{~h}$ & $72 \mathrm{~h}$ & \\
\hline Cmpd. & $\mathrm{C}[\mu \mathrm{g} / \mathrm{mL}]$ & MTT & & MTT & [3H]-thymidine \\
\hline ConA & 2.5 & $91.62 \pm 19.97$ & $115.67 \pm 24.71$ & ${ }^{*} 189.69 \pm 42.55$ & ${ }^{*} 926.57 \pm 169.21$ \\
\hline \multirow[t]{3}{*}{ a-ecdysone } & 2 & $69.76 \pm 32.29$ & $84.63 \pm 25.67$ & $76.04 \pm 26.90$ & $92.27 \pm 18.25$ \\
\hline & 10 & $89.51 \pm 22.83$ & $93.81 \pm 30.35$ & $85.59 \pm 24.40$ & $94.19 \pm 19.46$ \\
\hline & 20 & $91.97 \pm 25.74$ & $94.73 \pm 23.05$ & $97.07 \pm 26.87$ & $94.08 \pm 26.97$ \\
\hline \multirow[t]{3}{*}{ 20-hydroxy ecdysone } & 2 & $97.32 \pm 20.23$ & $97.69 \pm 29.34$ & $105.03 \pm 22.52$ & $99.21 \pm 21.45$ \\
\hline & 20 & $100.92 \pm 15.48$ & $102.92 \pm 27.78$ & $107.60 \pm 20.78$ & $100.13 \pm 27.84$ \\
\hline & 100 & $95.68 \pm 15.57$ & $102.05 \pm 25.34$ & $106.62 \pm 22.18$ & $92.71 \pm 26.51$ \\
\hline \multirow[t]{3}{*}{ sulfadiazine } & 2 & $95.74 \pm 12.74$ & $103.15 \pm 27.05$ & $107.30 \pm 26.87$ & $91.24 \pm 22.48$ \\
\hline & 20 & $98.37 \pm 18.35$ & $104.37 \pm 20.69$ & $107.00 \pm 26.21$ & $96.23 \pm 24.57$ \\
\hline & 100 & $100.63 \pm 19.82$ & $106.38 \pm 26.83$ & $104.51 \pm 21.83$ & $89.68 \pm 28.18$ \\
\hline
\end{tabular}

PBMCs isolated from individuals $(N=61)$ were tested in the presence of phytoecdysteroids and sulfadiazine in the concentration range between 2 and $100 \mu \mathrm{g} / \mathrm{mL}$ \pm SD at the incubation time from 24 to $72 \mathrm{~h}$. The statistically significant differences $(p<0.05)$ were labeled with an asterisk $(*)$; to calculate the decrease in the metabolic rate compared to the untreated blank, the following equation was used: viability measured using the $\mathrm{MTT}_{\mathrm{Tssay}}[\%]=100 \times$ sample $\mathrm{OD}_{570}$ (the mean value of the measured optical density of the test samples) / blank $\mathrm{OD}_{570}$ (the mean value of the measured optical density of the untreated cells); using the [ $\left.{ }^{3} \mathrm{H}\right]$ thymidine test: $100 \times$ mean cpm incorporated into treated cells / mean cpm incorporated into cells cultured without phytoecdysteroids 
positive and non-infected mice marked as Toxoplasmanegative were used for spleen isolation.

Single cell suspensions of splenocytes were obtained by spleen homogenization as described in [13]. The final spleen cells number was adjusted to $2.5 \times 10^{6}$ cells $/ \mathrm{mL}$ and used as host cells for T. gondii in vitro proliferation tests.

\section{In vitro studies on human PBMC and mouse splenocytes Cell viability assay}

The effects of phytoecdysteroids on the viability of human PBMC and mouse splenocytes were evaluated using the MTT [3-(4,5-dimethylthiazol-2-yl)-2,5-diphenyltetrazolium bromide] assay. The MTT assay was used according to international standards: ISO 10993-5:2009(E), Biological evaluation of medical devices, Part 5: Tests for in vitro cytotoxicity. The cells were placed into 96-well plates (Falcon) at a density of $2.5 \times 10^{5} / 100 \mu \mathrm{L} /$ well in culture medium and $100 \mu \mathrm{L}$ of tested phytoecdysteroids were added to the final concentrations of: $2 ; 10 ; 20 \mu \mathrm{g} / \mathrm{mL}$ of $\alpha$-ecdysone (Sigma-Aldrich) or 2; 20; $100 \mu \mathrm{g} / \mathrm{mL}$ of 20-hydroxyecdysone (Sigma-Aldrich). Cells cultured in the non-supplemented medium or stimulated with concanavalin A (ConA) (Sigma-Aldrich) at a concentration of $2.5 \mu \mathrm{g} / \mathrm{mL}$ served as a negative or positive control of proliferation, respectively. Afterwards, the cells were exposed to the tested compounds for $24 \mathrm{~h}$. Then, $1 \mathrm{mg} / \mathrm{mL}$ MTT (50 $\mu \mathrm{L} /$ well) was added to each well, incubated at $37^{\circ} \mathrm{C}, 10 \% \mathrm{CO}_{2}$ for $2 \mathrm{~h}$ and developed as described in [16]. The results were expressed as a viability percentage compared to the $2.5 \%$ DMSO treated controls. All experiments were performed in triplicate.

\section{Influence of phytoecdysteroids on PBMCs, splenocytes and T. gondii proliferation}

The human PBMC and mouse splenocytes were seeded in triplicate at $2.5 \times 10^{5}$ cells per well in 96-well tissue culture plates (Falcon) in: $100 \mu \mathrm{l}$ of culture medium with an equal number $\left(5 \times 10^{5} / 50 \mu \mathrm{L} /\right.$ each well, ratio 1 : 2) of $T$. gondii tachyzoites or only in $150 \mu$ l of culture medium. Then $50 \mu \mathrm{L}$ of culture medium with tested phytoecdysteroids was added to the final concentrations of: 2; 10; $20 \mu \mathrm{g} / \mathrm{mL}$ of $\alpha$-ecdysone (Sigma-Aldrich) and 2; 20; $100 \mu \mathrm{g} / \mathrm{mL}$ of 20-hydroxyecdysone (SigmaAldrich). Cells cultured in the non-supplemented medium or stimulated with concanavalin A (ConA) (Sigma-Aldrich) at a concentration of $2.5 \mu \mathrm{g} / \mathrm{mL}$ served as a negative or positive control of proliferation, respectively. The cultures were incubated at $37{ }^{\circ} \mathrm{C}$ for $48 \mathrm{~h}$ in humidified atmosphere with $10 \% \mathrm{CO}_{2}$ and $1 \mu \mathrm{Ci}$ of $[3 \mathrm{H}]$ uracil (Moravek Biochemicals Inc., USA) was then applied to each well for the last $20 \mathrm{~h}$. After the microscopic examination, the plates were frozen at $-20{ }^{\circ} \mathrm{C}$ and stored. Directly before the radioactivity measurement, the plate was thawed and tachyzoites and cells (PBMCs or splenocytes) were harvested with a semiautomatic cell harvester (SKATRON Instruments, Norway). Radioactivity (the level of $3[\mathrm{H}]$ uracil incorporation by toxoplasms or $3[\mathrm{H}]$ thymidyne by PBMCs and splenocytes) was measured using a 1450 Microbeta Plus Liquid Scintillation Counter (Wallac Oy, Finland). The cpms of control host cells (below 250/microculture) were subtracted from cpms of T. gondii infected microcultures.

\section{Quantitative Real-Time PCR}

T. gondii genomic DNA was isolated from the tachyzoites of the RH strain with the Wizard ${ }^{\circ}$ SV Genomic DNA Purification System (Promega, Madison, WI, USA) according to the manufacturer's instruction. The DNA concentration and purity were measured using a NanoPhotometer (Implen, München, Germany), while the integrity of the extracted DNA was tested using an ethidium bromide-stained agarose gel. DNA was used for the

Table 2 Effect of phytoecdysteroids on the intensity of T. gondii proliferation in human PBMCs

\begin{tabular}{|c|c|c|c|c|c|}
\hline \multirow[t]{3}{*}{ Cmpd. } & \multirow[t]{3}{*}{$C[\mu \mathrm{g} / \mathrm{mL}]$} & \multicolumn{4}{|c|}{ Proliferation of parasites [\%] in human PBMCs $(N=61)$} \\
\hline & & \multicolumn{2}{|c|}{ Toxo-seronegative $(N=40)$} & \multicolumn{2}{|c|}{ Toxo-seropositive $(N=21)$} \\
\hline & & {$\left[{ }^{3} \mathrm{H}\right]$ uracil } & qRT-PCR & {$\left[{ }^{3} \mathrm{H}\right]$ uracil } & qRT-PCR \\
\hline \multirow[t]{3}{*}{ a-ecdysone } & 2 & $90.59 \pm 19.20$ & nt & $86.04 \pm 27.57$ & $\mathrm{nt}$ \\
\hline & 10 & $105.35 \pm 25.33$ & $\mathrm{nt}$ & $98.06 \pm 21.55$ & nt \\
\hline & 20 & ${ }^{*} 115.09 \pm 21.26$ & ${ }^{*} 120.73 \pm 27.06$ & ${ }^{*} 140.74 \pm 57.33$ & ${ }^{*} 138.99 \pm 51.02$ \\
\hline \multirow[t]{3}{*}{ 20-hydroxy ecdysone } & 2 & $101.93 \pm 23.22$ & nt & ${ }^{*} 107.98 \pm 22.54$ & nt \\
\hline & 20 & ${ }^{*} 117.23 \pm 42.05$ & ${ }^{*} 122.82 \pm 30.58$ & ${ }^{*} 111.68 \pm 38.84$ & ${ }^{*} 109.32 \pm 26.28$ \\
\hline & 100 & $105.50 \pm 32.48$ & nt & $95.77 \pm 21.85$ & nt \\
\hline ConA & 2.5 & $92.62 \pm 29.98$ & nt & $102.62 \pm 25.35$ & nt \\
\hline
\end{tabular}

PBMCs isolated from individuals $(N=61)$ were tested in the presence of phytoecdysteroids and ConA in the concentration range between 2 and $100 \mu \mathrm{g} / \mathrm{mL} \pm \mathrm{SD}$. Incubation period was $72 \mathrm{~h}$. The statistically significant differences $(p<0.05)$ were labeled with an asterisk $\left(^{*}\right)$. To calculate the intensity of Toxoplasma proliferation compared to the untreated blank, the following equation was used: proliferation [\%] $=100 \times$ mean cpm incorporated into the treated cells in the [ $\left.{ }^{3} \mathrm{H}\right]$ uracil test or B1 gene in the qRT-PCR assay / mean cpm incorporated into the cultured cells or B1 gene without phytoecdysteroids 
detection and quantitation of $T$. gondii in analyzed samples and it was stored at $-20{ }^{\circ} \mathrm{C}$. A quantitative real-time PCR (qRT-PCR) assay, targeting B1 gene [25] was performed to detect and to quantitate $T$. gondii in analyzed samples according to the modified protocol of Wahab et al. [26]. All samples were analyzed in triplicate.

\section{Antibody and cytokine ELISAs}

The T. gondii serological status of all human sera was checked by the determination of anti-T. gondii IgG and IgM antibodies using commercially available ELISA kits (NovaLisa $^{\mathrm{mm}}$ IgG and NovaLisa ${ }^{\mathrm{m}}$ IgM $\mu$-capture; Nova-Tec Immundiagnostica $\mathrm{GmbH}$, Germany). Sera were recognized as IgM-positive at NTK (NovaTec Units, NovaTec Immundiagnostica $\mathrm{GmbH}$ ) level $>11$ and IgG-positive at $>35 \mathrm{IU} / \mathrm{mL}$. Overall, it was found that almost one-third of the tested volunteers were infected by $T$. gondii and the seroprevalence among men was slightly higher ( $38 \%, N=$ $21)$ than among women $(29 \%, N=43)$.

The levels of human and mice IFN- $\gamma$, IL-2, IL-4 and IL-10 were measured in the human PBMC and mouse splenocytes culture supernatants using commercially available ELISA sets (OptEIA ${ }^{\mathrm{mix}}$, BD Biosciences, Poland). The supernatants were collected at $24 \mathrm{~h}$ for IL-4, $48 \mathrm{~h}$ for IL-2 and $72 \mathrm{~h}$ for IFN- $\gamma$ and IL-10 from non-infected cultures and after Toxoplasma infection. The assays were carried out according to the manufacturer's instructions. The detection limits for each cytokine were as follows: $3.1 \mathrm{pg} / \mathrm{mL}$ (mouse IL-2), $4.7 \mathrm{pg} /$ $\mathrm{mL}$ (human IFN- $\gamma$ ), $7.8 \mathrm{pg} / \mathrm{mL}$ (human IL-10, mouse IL-4) and $31.3 \mathrm{pg} / \mathrm{mL}$ (mouse IL-10 and IFN- $\gamma$ ).

\section{Statistics}

Statistical analysis was performed using SigmaStat 3.5 (Systat Software GmbH). The Kolmogorov-Smirnov test was applied for assessing the normality of the data distribution. The t-student or U-Mann-Whitney test was used for comparing two groups. For multiple comparisons the Kruskal-Wallis test or one-way ANOVA were performed. Differences with a two-tailed value of $p<0.05$ were considered as statistically significant. The best-fit $\mathrm{IC}_{50}$ curves
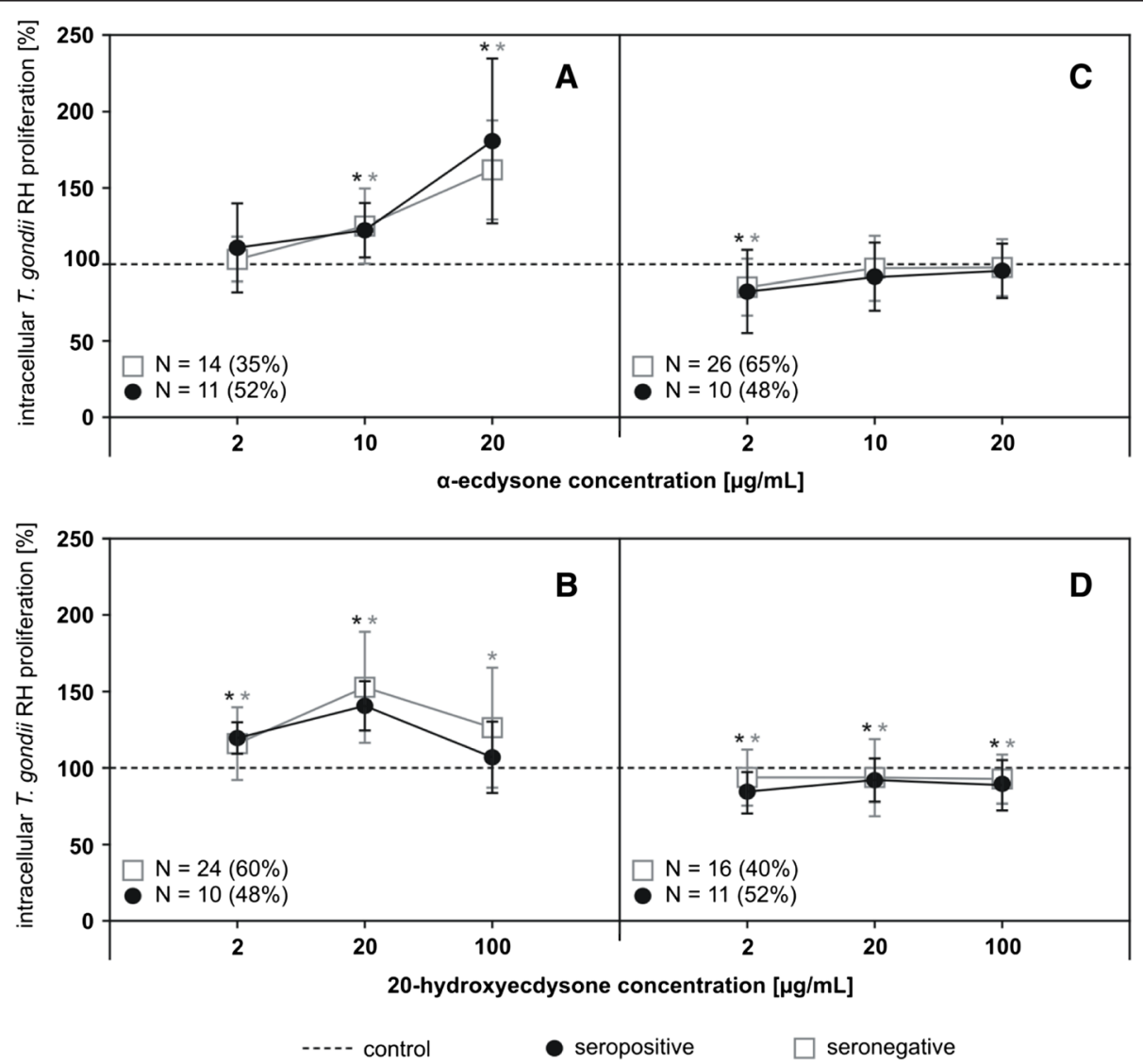

Fig. 1 Effect of a-ecdysone and 20-hydroxyecdysone on T. gondii proliferation in PBMCs. PBMCs from Toxo-seronegative ( $\square$ ) and Toxo-seropositive (•) individuals, in the groups with observed, statistically significant (,$N=26$ and $B, N=34$ ) and non-observed $(C, N=36$ and $D, N=26)$ T. gondii proliferation, in the presence of the tested compounds, after $72 \mathrm{~h}$ of incubation 


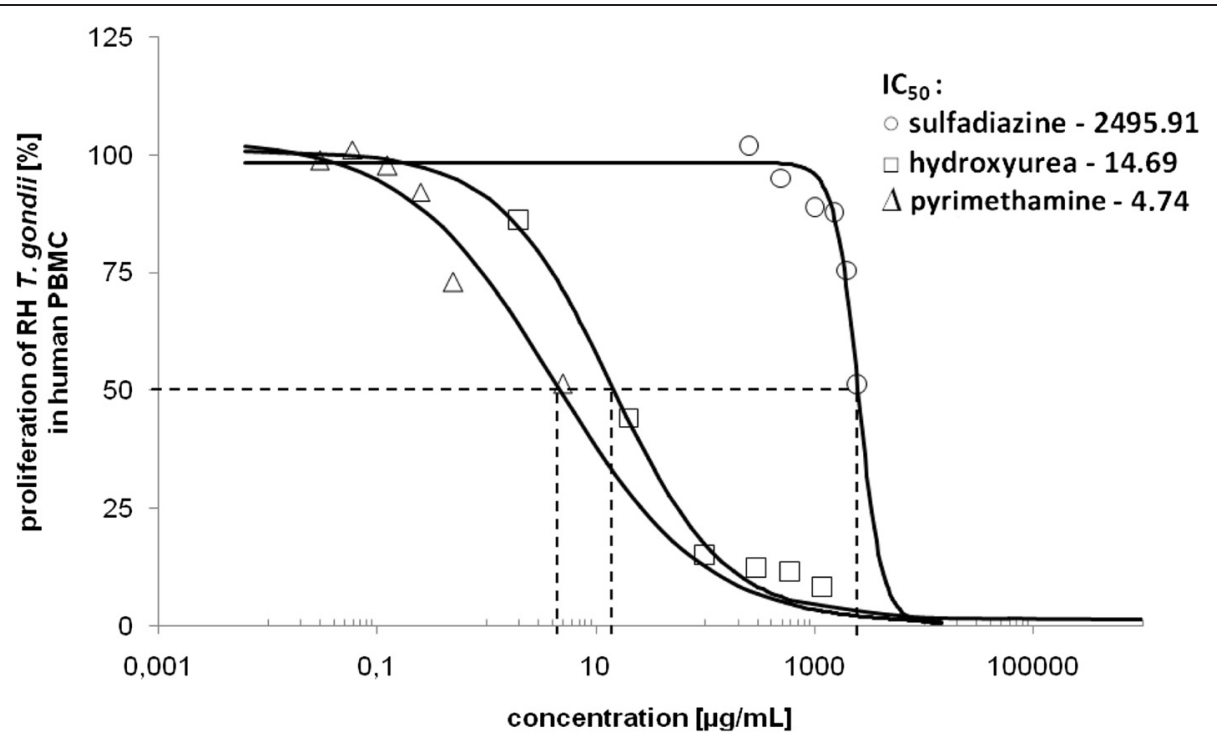

Fig. 2 Estimation of $I C_{50}[\mu \mathrm{g} / \mathrm{mL}]$ values of sulfadiazine, pyrimethamine and hydroxyurea in $T$. gondii infected human PBMCs

were plotted using GraphPad Prism 6.0 (GraphPad Software, Inc.).

\section{Results and Discussion}

T. gondii has developed numerous mechanisms which enable it to colonize various cell types, alter their function and use them as a reservoir of infection. While $T$. gondii reproduces sexually only in feline enterocytes [27], it uses predominantly neural and muscle cells to survive and form tissue cysts [28]. Moreover, the parasite hijacks blood nucleated cells turning them into Trojan horses so that the infection disseminates throughout the host's organism. With consideration to the variety of hosts and tissues which can be invaded by this parasite, two different cell types were chosen for the research: human peripheral blood mononuclear cells (PBMCs) and murine splenocytes. We also used two different mouse strains characterized by low $(\mathrm{BALB} / \mathrm{c})$ and high $(\mathrm{C} 57 \mathrm{BL} / 6)$ innate susceptibility to toxoplasmosis. Moreover, both human and mouse cells were collected from T. gondii seronegative as well as seropositive individuals.

In the first step of experiments aimed at checking the anti-toxoplasmic activity of selected phytoecdysteroids, we assessed the potential cytotoxicity of $\alpha$-ecdysone and 20-

Table 3 Effect of the studied phytoecdysteroids on the intensity of RH T. gondii proliferation

\begin{tabular}{|c|c|c|c|c|}
\hline \multirow[t]{3}{*}{ Cmpd. } & \multirow[t]{3}{*}{$C[\mu \mathrm{g} / \mathrm{mL}]$} & \multicolumn{3}{|c|}{ Proliferation of parasites [\%] in mouse splenocytes } \\
\hline & & \multicolumn{2}{|l|}{$\mathrm{BALB} / \mathrm{C}$} & \multirow{2}{*}{$\frac{\text { C57BL/6 }}{\text { Toxo-negative }(N=10)}$} \\
\hline & & Toxo-positive $(N=10)$ & Toxo-negative $(N=14)$ & \\
\hline \multirow[t]{3}{*}{ a-ecdysone } & 2 & $89.29 \pm 5.90 \downarrow$ & $67.77 \pm 5.05^{*} \downarrow$ & $89.69 \pm 2.54 \downarrow$ \\
\hline & 10 & $91.17 \pm 2.89 \downarrow 10 \%$ & $75.69 \pm 2.34^{*} \downarrow 39 \%$ & $99.75 \pm 2.57 \downarrow 13 \%$ \\
\hline & 20 & $99.29 \pm 4.14 \downarrow$ & $106.63 \pm 2.67^{*} \downarrow$ & $102.58 \pm 1.85 \downarrow$ \\
\hline \multirow[t]{3}{*}{ 20-hydroxy ecdysone } & 2 & $88.65 \pm 2.55$ & $80.81 \pm 3.35^{*}$ & $99.30 \pm 2.55$ \\
\hline & 20 & $88.82 \pm 3.11$ & $109.28 \pm 2.11^{*}$ & $103.73 \pm 3.94$ \\
\hline & 100 & $90.02 \pm 0.52$ & $92.05 \pm 2.34$ & $97.76 \pm 1.85$ \\
\hline \multirow[t]{3}{*}{ sulfadiazine } & 2 & $92.91 \pm 5.11$ & $78.34 \pm 5.14^{*}$ & $85.79 \pm 1.55^{*}$ \\
\hline & 20 & $94.18 \pm 2.35$ & $70.87 \pm 3.11^{*}$ & $74.65 \pm 2.48^{*}$ \\
\hline & 100 & $81.48 \pm 1.52$ & $65.32 \pm 3.09^{*}$ & $62.31 \pm 2.88^{*}$ \\
\hline ConA & 2.5 & $192.60 \pm 9.65^{*}$ & $151.48 \pm 8.97^{*}$ & $191.62 \pm 9.97^{*}$ \\
\hline
\end{tabular}

Parasite proliferation was tested on splenocytes obtained from BALB/c mice previously infected with DX T. gondii (Toxo-positive), BALB/C and C57BL/6 uninfected (Toxo-negative) mice, using $\left[{ }^{3} \mathrm{H}\right]$ uracil incorporation. The statistically significant differences $(p<0.05)$ were labeled with an asterisk $(*) ; \downarrow$ indicates an increasing pool of protozoans with the increasing concentration of phytoecdysteroids in the splenocyte cultures 
hydroxyecdysone using the MTT assay and $\left[{ }^{3} \mathrm{H}\right]$-thymidine incorporation test. As we expected [29, 30], all cells responded positively after stimulation with the concanavalin A mitogen $(p<0.05)$ in the control microcultures. Importantly, neither phytoecdysteroids showed cytotoxic effect on PBMCs (Table 1) nor murine splenocytes (data not shown).

The effect of two selected phytoecdysteroids ( $\alpha$-ecdysone and 20-hydroxyecdysone) on T. gondii proliferation was assessed by the $\left[{ }^{3} \mathrm{H}\right]$-uracil radioisotope method, in which the tritiated uracil is selectively incorporated into the parasite's nucleic acids by a highly active uracil phosphoribosyltransferase and uridine phosphorylase [31]. The qRT-PCR test was additionally performed to confirm the observation. The obtained results (Table 2) showed that neither compound proved to have inhibitory effect on $T$. gondii growth in human leukocyte cultures. Moreover they even stimulated the tachyzoites to proliferate. Furthermore, we observed the same phenomenon regardless of the serological status of the host cell donors. T. gondii proliferated more intensively as the concentration of $\alpha$-ecdysone increased and at $20 \mu \mathrm{g} / \mathrm{mL}$ the number of the parasite's daughter cells in PBMCs was higher by $15.05 \pm 21.26 \%(p<0.05)$ for seronegative and by $40.74 \pm 57.33 \%(p<0.05)$ for seropositive individuals, compared to controls. In the case of 20-hydroxyecdysone, a significant increase in the parasite proliferation was observed only at the concentration of $20 \mu \mathrm{g} / \mathrm{mL}$, i.e., $17.23 \pm 42.05 \%(p<0.05)$ for seronegative and $11.68 \pm 18.84 \%(p<0.05)$ for seropositive individuals. As shown in Table 2, these results were confirmed by qRT-PCR.

Due to a relatively high spread of the obtained results, we performed a further analysis of the detailed data (Fig. 1). The analysis led to the conclusion that within the seronegative and seropositive individuals, two subgroups could be identified: individuals whose cells were influenced by the tested compounds (Fig. 1, group A and B) or those who did not seem to be affected (Fig. 1, group $C$ and $D$ ). In the groups $A$ and $B$ the level of parasite proliferation in PBMCs, in the presence of the highest tested concentration of $\alpha$-ecdysone increased by $62 \% \pm 32(p<0.05)$ or $81 \% \pm 53(p<0.05)$ compared to the average values in seronegative and seropositive groups, respectively. At $20 \mu \mathrm{g} / \mathrm{mL}$ of $20-$ hydroxyecdysone a similar increase was observed, i.e., $52 \% \pm 36(p<0.05)$ in seronegative and $40 \% \pm 17(p<$ 0.05 ) in seropositive individuals, as compared to controls.

It was also found that the addition of concanavalin $\mathrm{A}$ to the tested cultures did not affect the final level of $T$. gondii proliferation; most likely because the host cells were unable to respond to a mitogen as quickly as the invasion of the parasites occurred. For comparative purposes we tested parallelly three different chemical agents able to restrict RH T. gondii growth: sulfadiazine and pirymethamine (used as recommended drugs in the therapy of toxoplasmosis) as well as hydroxyurea (used in anti-tumor therapy or in research) as a positive controls. In Fig. 2 we present the $\mathrm{IC}_{50}$ values for

Table 4 Cytokine profiles corresponding to human PBMCs cultured in the presence of phytoecdysteroids or concanavalin A

\begin{tabular}{|c|c|c|c|c|c|c|c|c|c|}
\hline \multirow{4}{*}{ PBMCS } & & \multicolumn{8}{|c|}{ Cytokine levels [pg/mL] } \\
\hline & & \multirow{2}{*}{\multicolumn{2}{|c|}{ control }} & \multirow{2}{*}{\multicolumn{2}{|c|}{ a-ecdysone }} & \multicolumn{3}{|c|}{ 20-hydroxyecdysone } & \multirow[t]{2}{*}{ ConA } \\
\hline & & & & & & & & & \\
\hline & & 0 & 2 & 10 & 20 & 2 & 20 & 100 & 2.5 \\
\hline A. & mean & 126.75 & 132.52 & 129.92 & 125.68 & 127.04 & 124.58 & 131.26 & $2661.02^{*}$ \\
\hline \multirow[t]{2}{*}{$N=52$} & SD & 106.20 & 121.25 & 114.94 & 114.31 & 123.67 & 116.29 & 127.42 & 1197.77 \\
\hline & median & 118.26 & 127.32 & 120.45 & 121.71 & 120.44 & 122.88 & 212.62 & 2238.19 \\
\hline B. & mean & 11.96 & 7.85 & 10.86 & 11.23 & 7.12 & 7.74 & 9.96 & $1003.35^{*}$ \\
\hline \multirow[t]{3}{*}{$N=8$} & SD & 10.16 & 1.94 & 4.32 & 4.25 & 1.57 & 0.97 & 5.04 & 414.06 \\
\hline & median & 7.21 & 7.97 & 9.32 & 9.63 & 7.07 & 7.75 & 7.51 & 107.77 \\
\hline & & \multicolumn{8}{|c|}{$\mathrm{IL}-10$} \\
\hline A. & mean & 240.76 & 255.75 & 297.50 & 311.00 & 255.81 & 296.75 & 301.58 & $2758.74^{*}$ \\
\hline \multirow[t]{2}{*}{$N=48$} & SD & 206.93 & 202.64 & 236.93 & 253.40 & 183.88 & 183.35 & 243.97 & 1075.34 \\
\hline & median & 143.54 & 209.02 & 199.84 & 286.51 & 254.64 & 286.36 & 327.35 & 2849.68 \\
\hline B. & mean & 13.12 & 8.56 & 8.66 & 7.23 & 9.89 & 8.93 & 11.30 & $606.68^{*}$ \\
\hline \multirow[t]{2}{*}{$N=9$} & SD & 3.09 & 1.39 & 2.25 & 1.50 & 2.43 & 3.95 & 7.10 & 196.97 \\
\hline & median & 13.00 & 8.79 & 8.79 & 7.60 & 10.57 & 7.90 & 8.79 & 574.96 \\
\hline
\end{tabular}


sulfadiazine $\left(\mathrm{IC}_{50}=2495.91 \mu \mathrm{g} / \mathrm{mL}\right)$, pyrimethamine $\left(\mathrm{IC}_{50}=14.69 \mu \mathrm{g} / \mathrm{mL}\right)$ and hydroxyurea $\left(\mathrm{IC}_{50}=4.74 \mu \mathrm{g} /\right.$ $\mathrm{mL}$ ) against $\mathrm{RH} T$. gondii proliferating in normal human cells (PBMCs) at the parasite-host cell ratio of 2:1. Numerous studies proved that $T$. gondii susceptibility to a drug depends both on the invading strain and the host cells to be infected. Using the RH strain and different normal host cells, i.e., human MRC-5 [32], Vero [33], HFF [34] the $\mathrm{IC}_{50}$ values of sulfadiazine ranged from 2.5 to $77 \mu \mathrm{g} / \mathrm{mL}$. In contrast to this, the use of human carcinoma HEp-2 [35] or HeLa [36] cells changed the $\mathrm{IC}_{50}$ to, $600-700$ or $>1000 \mu \mathrm{g} / \mathrm{mL}$, respectively. As our observations reveal, the determination of the $\mathrm{IC}_{50}$ for a certain parasite strain is closely related to the type of host cells and also to the parasite load used.

In order to verify the obtained results the same experiments on two strains of inbred mice, characterized by low $(\mathrm{BALB} / \mathrm{c})$ or high $(\mathrm{C} 57 \mathrm{BL} / 6)$ innate susceptibility to T. gondii infection were performed. We analyzed the effect of phytoecdysteroids on the parasite proliferation in murine splenocytes derived from both uninfected and $T$. gondii-infected animals. Chronic toxoplasmosis was induced by a challenge with the DX strain and the presence of tissue cysts in brains of infected mice was confirmed microscopically just before the isolation of spleen cells. The parasite load ranged from 450 to 600 cysts per brain. We observed that the intensity of parasite proliferation in host cells collected from both mouse strains correlated with the increasing concentration of $\alpha$-ecdysone; however, only in the case of the group of uninfected BALB/c mice the proliferation increase was statistically significant $(38.86 \%, p<0.05$; Table 3$)$.

Ecdysteroids have been reported to exhibit a wide array of positive pharmacological effects on mammals, including carbohydrate, lipid and protein metabolism. Hence, multiple ecdysteroid-containing preparations are already commercially available, for instance as dietary supplements for sportsmen. Since ecdysteroids are considered as potential therapeutic drugs, it is essential to determine their effect on various pathogens. In general, the impact of phytoecdysteroids on parasites is poorly understood and does not explain the mechanisms of their action, which appears to vary in different parasites. While 20-hydroxyecdysone showed a significant inhibition of another apicomplexan parasite Babesia gibsoni [24], our results surprisingly demonstrated that phytoecdysteroids did not inhibit, but even promoted the multiplication of Toxoplasma gondii both in the human and murine immunocompetent cells. These observations are reflected by literature data referring to parasites such as Trypanosoma cruzi, which cause trypanosomiasis (Chagas disease) in humans and animals [37]. Barker et al. [38] reported that ecdysone can play a hormonal role in filarial worms similar to that found in insects. Namely, ecdysone was found to stimulate the microfilarial release in Brugia pahangi (a filarial worm of dogs and cats) and to control the meiotic reinitiation in the oocytes of Dirofilaria immitis (a roundworm spread by mosquitoes). It has been also demonstrated that Onchocerca volvulus and Onchocerca lienalis microfilariae increase their

Table 5 Cytokine profiles corresponding to human PBMCs infected by T. gondii and incubated with phytoecdysteroids or concanavalin A

\begin{tabular}{|c|c|c|c|c|c|c|c|c|c|}
\hline \multirow{4}{*}{$\begin{array}{l}\text { PBMCs and } \\
\text { Toxoplasma }\end{array}$} & & \multicolumn{8}{|c|}{ Cytokine levels [pg/mL] } \\
\hline & & \multirow{2}{*}{\multicolumn{2}{|c|}{ control }} & \multirow{2}{*}{\multicolumn{2}{|c|}{ a-ecdysone }} & \multicolumn{3}{|c|}{ 20-hydroxyecdysone } & \multirow[t]{2}{*}{ ConA } \\
\hline & & & & & & & & & \\
\hline & & 0 & 2 & 10 & 20 & 2 & 20 & 100 & 2.5 \\
\hline A. & mean & 579.94 & 668.42 & 644.86 & 601.85 & 612.61 & 603.78 & 615.51 & $1040.90^{*}$ \\
\hline \multirow[t]{2}{*}{$N=49$} & SD & 552.02 & 541.49 & 515.38 & 500.54 & 540.02 & 524.31 & 522.29 & 543.24 \\
\hline & median & 362.98 & 441.04 & 448.27 & 494.70 & 464.31 & 422.97 & 492.39 & 941.43 \\
\hline B. & mean & 58.30 & 91.36 & 79.17 & 74.69 & 67.42 & 64.34 & 75.88 & $171.39^{*}$ \\
\hline \multirow[t]{3}{*}{$N=10$} & SD & 35.80 & 65.93 & 50.10 & 46.09 & 35.78 & 40.41 & 50.66 & 68.67 \\
\hline & median & 61.19 & 68.31 & 71.24 & 83.38 & 65.14 & 59.40 & 75.96 & 163.96 \\
\hline & & \multicolumn{8}{|c|}{$\mathrm{IL}-10$} \\
\hline A. & mean & 622.90 & 542.24 & 616.43 & 706.24 & 608.92 & 660.99 & 623.21 & 728.45 \\
\hline \multirow[t]{2}{*}{$N=46$} & $S D$ & 309.04 & 338.16 & 292.83 & 350.71 & 311.57 & 309.01 & 328.14 & 589.63 \\
\hline & median & 521.62 & 455.37 & 491.01 & 566.36 & 562.35 & 523.13 & 500.08 & 681.18 \\
\hline B. & mean & 68.94 & 46.73 & 65.46 & 81.36 & 51.35 & 57.03 & 62.39 & 88.98 \\
\hline \multirow[t]{2}{*}{$N=12$} & SD & 51.28 & 33.14 & 44.68 & 46.89 & 31.61 & 41.42 & 45.79 & 51.47 \\
\hline & median & 41.48 & 38.49 & 40.54 & 56.04 & 40.38 & 37.97 & 39.59 & 68.94 \\
\hline
\end{tabular}


metabolic activity when treated in vitro with 20hydroxyecdysone [39]. In the light of these observations, it is particularly important to consider the effect of ecdysteroids on immunocompromised patients, such as HIV-infected individuals, which are in a particular danger of developing a superinfection. Analogously to HIVassociated toxoplasmosis, patients infected with human T-cell leukaemia virus type I (HTLV-1) develop frequently a severe strongyloidiasis caused by a nematode Strongyloides stercoralis [40]. Although the moulting process in parasitic nematodes is very complex being possibly regulated by more than one transcriptional cascade, there is evidence that steroids, including ecdysteroids, may up-regulate the moulting signalling within the S. stercoralis larvae and it might be caused by a presence of a nuclear hormone receptor of the steroid/thyroid hormone-receptor superfamily [41, 42].

Ecdysteroids display hormonal function in insects (moulting hormones). However, their pharmacological effects on humans and animals cannot be simply considered as hormonal activity. The use of phytoecdysteroids in humans and animals has been proposed on the basis of their supposed interference with steroidal metabolic pathways of mammals. While the main focus remains on estrogenic and anabolic effects in humans [43] and domestic animals [44, 45], little has been published on these compounds' immunomodulatory and antiinflammatory potential. Trenin and Volodin [46] described 20-hydroxyecdysone as a human lymphocyte and neutrophil modulator. 20-hydroxyecdysone was also revealed to modulate the fluoride-stimulated respiratory burst of human neutrophils in the same manner as water soluble antioxidants. Moreover, 20hydroxyecdysone dramatically attenuated renal injury in diabetes model. The authors concluded that 20hydroxyecdysone might act through suppressing postreceptor signalling of TGF- $\beta 1$. [47]. On the contrary, Harmatha et al. [48] found that 20-hydroxyecdysone did not influence the intensity of nitric oxide biosynthesis in mouse resident peritoneal macrophages stimulated by interferon- $\gamma$, and lipopolysaccharide. Similarly, Tanaguchi et al. [49] also did not observe any antiinflammatory effect of 20-hydroxyecdysone in rats. Data obtained by Peschel et al. [50] in the HeLa-IL-6

Table 6 Cytokine profiles corresponding to the mice splenocytes cultivated in the presence of phytoecdysteroids and concanavalin A

\begin{tabular}{|c|c|c|c|c|c|c|c|c|c|}
\hline \multirow{4}{*}{ Splenocytes } & & \multicolumn{8}{|c|}{ Cytokine levels [pg/mL] } \\
\hline & & \multirow{2}{*}{\multicolumn{2}{|c|}{ control }} & \multirow{2}{*}{\multicolumn{2}{|c|}{ a-ecdysone }} & \multicolumn{3}{|c|}{ 20-hydroxyecdysone } & \multirow[t]{2}{*}{ ConA } \\
\hline & & & & & & \multicolumn{3}{|c|}{$\mathrm{IFN}-\gamma$} & \\
\hline & & 0 & 2 & 10 & 20 & 2 & 20 & 100 & 2.5 \\
\hline $\mathrm{BALB} / \mathrm{C}$ & mean & 752.33 & 606.89 & 552.24 & 667.61 & 716.58 & 709.40 & 663.52 & $1997.97^{*}$ \\
\hline$N=12$ & SD & 634.53 & 423.51 & 438.02 & 599.92 & 452.11 & 568.89 & 409.02 & 369.25 \\
\hline negative & median & 48.28 & 566.79 & 498.71 & 632.57 & 666.49 & 657.71 & 565.57 & 1857.23 \\
\hline $\mathrm{BALB} / \mathrm{C}$ & mean & 1735.99 & 1000.17 & 1168.71 & 1057.95 & 1540.23 & 1661.91 & 1560.54 & $4307.02^{*}$ \\
\hline$N=9$ & SD & 714.81 & 687.62 & 843.80 & 901.84 & 572.05 & 604.58 & 633.65 & 82.08 \\
\hline \multirow[t]{2}{*}{ positive } & median & 1848.28 & 878.07 & 976.23 & 819.85 & 1385.37 & 1485.31 & 1439.19 & 4292.66 \\
\hline & & \multicolumn{8}{|c|}{$\mathrm{IL}-10$} \\
\hline $\mathrm{BALB} / \mathrm{C}$ & mean & 19.49 & 20.84 & 18.87 & 19.60 & 21.39 & 19.20 & 20.54 & $1987.46^{*}$ \\
\hline$N=12$ & SD & 9.08 & 13.12 & 7.80 & 10.45 & 8.12 & 8.85 & 9.55 & 340.02 \\
\hline negative & median & 16.30 & 18.58 & 16.08 & 17.56 & 19.86 & 17.48 & 18.96 & 1883.19 \\
\hline $\mathrm{BALB} / \mathrm{C}$ & mean & 1344.07 & 1351.45 & 1385.59 & 1426.28 & 1550.71 & 1390.64 & 1437.98 & $2531.09^{*}$ \\
\hline$N=9$ & SD & 583.19 & 543.89 & 550.90 & 522.69 & 506.47 & 494.77 & 521.20 & 661.58 \\
\hline \multirow[t]{2}{*}{ positive } & median & 972.59 & 975.12 & 1006.89 & 1084.91 & 1228.71 & 1158.47 & 1079.78 & 2878.76 \\
\hline & & \multicolumn{8}{|c|}{ IL-2 } \\
\hline $\mathrm{BALB} / \mathrm{C}$ & mean & 11.58 & 9.85 & 9.04 & 9.64 & 9.54 & 10.63 & 9.71 & $159.12^{*}$ \\
\hline$N=10$ & SD & 9.76 & 2,55 & 3.32 & 3.21 & 3.82 & 3.79 & 3.23 & 30.02 \\
\hline negative & median & 10.03 & 8.01 & 7.96 & 7.86 & 7.32 & 8.56 & 8.56 & 143.45 \\
\hline $\mathrm{BALB} / \mathrm{C}$ & mean & 16.22 & 21.82 & 15.88 & 19.91 & 19.31 & 19.80 & 20.98 & $276.97^{*}$ \\
\hline$N=10$ & SD & 10.25 & 11.48 & 8.83 & 13.63 & 15.55 & 12.89 & 13.42 & 42.75 \\
\hline positive & median & 15.25 & 17.77 & 14.25 & 16.45 & 13.55 & 15.50 & 19.05 & 290.12 \\
\hline
\end{tabular}

Splenocytes were derived from BALB/C mice uninfected (T. gondii-seronegative) and chronically infected with $T$. gondii DX strain (T. gondii-seropositive). The statistically significant differences $(p<0.05)$ were labeled with an asterisk $\left(^{*}\right)$ 
model (cells stably transfected with an IL-6-bound reporter gen) implied a 20-hydroxyecdysone caused inhibition of nuclear factor - kappa B (NF-kB), which plays a central role in cellular immune response, inflammation and cell fate. The situation is different when standard human epithelial cells are infected with intracellular parasite such as T. gondii. Kim et al. [51] reported that $T$. gondii $\mathrm{RH}$ strain infected HeLa cells induced NF- $\mathrm{kB}$ and increased the expression of two chemokines: IL-8 and monocyte chemotactic protein-1 (MCP-1) mRNA. Moreover, the addition of IL-1 $\alpha$ to $T$. gondii cultures increased the activation of NF- $\mathrm{kB}$ and IL-8 transcriptional reporters, compared to tachyzoiteinfected cells without IL- $1 \alpha$ treatment. However, the described phenomenon is not unequivocal because various studies showed that Toxoplasma has developed many strategies that can modulate the host NF-kB pathway. Evidence currently exists for both inhibition [52, 53] or activation [54-57] of the NF- $\mathrm{KB}$ pathway in host cell infected by Toxoplasma resulting in suppressed proinflammatory cytokine expression and enhanced survival of the pathogen or inhibition of

Table 7 Cytokine profiles corresponding to the splenocytes infected by T. gondii and cultivated in the presence of phytoecdysteroids or concanavalin A

\begin{tabular}{|c|c|c|c|c|c|c|c|c|c|}
\hline \multirow{4}{*}{\multicolumn{2}{|c|}{$\begin{array}{l}\text { Splenocytes and } \\
\text { toxoplasma }\end{array}$}} & \multicolumn{8}{|c|}{ Cytokine levels [pg/mL] } \\
\hline & & \multirow{3}{*}{$\begin{array}{l}\text { control } \\
0\end{array}$} & \multicolumn{3}{|c|}{ a-ecdysone } & \multirow{2}{*}{\multicolumn{3}{|c|}{ 20-hydroxyecdysone }} & \multirow{3}{*}{$\begin{array}{l}\text { ConA } \\
2.5 \\
\end{array}$} \\
\hline & & & \multicolumn{3}{|c|}{$\mathrm{IFN}-\gamma$} & & & & \\
\hline & & & 2 & 10 & 20 & 2 & 20 & 100 & \\
\hline BALB/C & mean & 1776.41 & 1748.22 & 1809.40 & $1263.67^{*}$ & 1431.23 & $908.90^{*}$ & 1860.88 & $2236.53^{*}$ \\
\hline$N=14$ & SD & 672.75 & 452.11 & 568.89 & 109.02 & 760.64 & 200.90 & 1275.54 & 469.06 \\
\hline negative & median & 1626.60 & 1666.49 & 1884.71 & 1265.57 & 1303.56 & 898.47 & 1854.40 & 1952.70 \\
\hline $\mathrm{BALB} / \mathrm{C}$ & mean & 2081.82 & 2983.11 & 2907.12 & 2912.51 & 2965.06 & 2884.66 & 2950.60 & $4159.40^{*}$ \\
\hline$N=10$ & SD & 1253.55 & 1390.12 & 1445.01 & 1497.61 & 1541.11 & 1531.37 & 1477.52 & 322.44 \\
\hline positive & median & 1604.36 & 3972.21 & 3812.13 & 3954.39 & 4070.46 & 3987.08 & 3984.11 & 4198.95 \\
\hline $\mathrm{C} 57 \mathrm{Bl} / 6$ & mean & 816.88 & 790.06 & 749.12 & 827.65 & 639.40 & 652.87 & 765.19 & $3569.88^{*}$ \\
\hline$N=10$ & $\mathrm{SD}$ & 326.21 & 278.98 & 237.76 & 232.67 & 232.76 & 245.14 & 219.75 & 378.49 \\
\hline \multirow[t]{2}{*}{ negative } & median & 787.18 & 698.90 & 678.65 & 743.09 & 606.98 & 120.28 & 136.92 & 3339.78 \\
\hline & & \multicolumn{8}{|c|}{ IL-10 } \\
\hline BALB/C & mean & 534.73 & 531.39 & 538.11 & 639.41 & 631.99 & 535.42 & 631.71 & $1987.46^{*}$ \\
\hline$N=14$ & SD & 369.76 & 367.85 & 317.15 & 411.98 & 310.57 & 410.32 & 418.65 & 440.02 \\
\hline negative & median & 532.30 & 531.08 & 532.00 & 636.93 & 629.86 & 533.53 & 528.94 & 2083.19 \\
\hline BALB/C & mean & 1836.67 & 2054.01 & 1783.78 & 1907.01 & 2252.42 & 1981.89 & 1942.38 & $3157.88^{*}$ \\
\hline$N=10$ & SD & 387.73 & 579.95 & 716.93 & 499.15 & 592.62 & 392.76 & 433.08 & 1186.99 \\
\hline positive & median & 1638.48 & 1952.01 & 1540.04 & 1691.38 & 1946.47 & 1760.87 & 1821.10 & 3615.60 \\
\hline C57BI/6 & mean & 28.73 & 30.68 & 33.36 & 28.94 & 29.59 & 31.75 & 25.98 & $516.83^{*}$ \\
\hline$N=9$ & SD & 20.33 & 24.72 & 27.19 & 19.04 & 17.88 & 16.70 & 19.85 & 378.49 \\
\hline \multirow[t]{2}{*}{ negative } & median & 25.46 & 28.56 & 29.46 & 25.98 & 26.58 & 29.87 & 34.56 & 501.78 \\
\hline & & \multicolumn{8}{|c|}{$\mathrm{IL}-2$} \\
\hline $\mathrm{BALB} / \mathrm{C}$ & mean & 22.98 & 20.22 & 20.69 & 23.24 & 21.45 & 26.25 & 24.47 & $163.68^{*}$ \\
\hline$N=10$ & SD & 20.69 & 19.85 & 19.87 & 18.23 & 16.59 & 20.69 & 20.58 & 54,76 \\
\hline negative & median & 21.20 & 20.30 & 19.58 & 19.23 & 19.96 & 19.65 & 22.87 & 139.78 \\
\hline BALB/C & mean & 124.42 & 151.08 & 130.26 & 140.97 & 149.61 & 146.26 & 166.44 & $339.63^{*}$ \\
\hline$N=10$ & $\mathrm{SD}$ & 69.58 & 64.59 & 56.79 & 56.89 & 76.40 & 72.27 & 69.21 & 14.84 \\
\hline positive & median & 87.18 & 120.20 & 116.25 & 125.37 & 131.56 & 120.28 & 136.92 & 339.78 \\
\hline C57Bl/6 & mean & 12.54 & 10.02 & 10.17 & 10.29 & 11.42 & 12.26 & 11.87 & $163.68^{*}$ \\
\hline$N=10$ & SD & 10.70 & 9.08 & 9.57 & 8.92 & 6.38 & 10.84 & 10.10 & 54,76 \\
\hline negative & median & 10.25 & 10.00 & 9.25 & 9.98 & 10.25 & 10.24 & 10.36 & 139.78 \\
\hline
\end{tabular}


apoptosis, an important defence mechanism against intracellular pathogens. The described results were dependent for example on whether in vivo or in vitro conditions were analyzed [53], what type of strain and techniques were used in the experiments. For example, infection with type I strain inhibited the NF- $\mathrm{B}$ pathway and down-regulated the production of IL-12, thus limiting protective $\mathrm{T}$ helper 1(Th1)-type cytokine (IFN$\gamma$, IL-2) response [52, 58] while Toxoplasma type II parasites activated the NF- $\mathrm{kB}$ p 65 subunit [54]. It was confirmed that the observed differences were related to the various expression levels of ROP18 [52] or GRA15 [54] proteins, being some of the crucial antigens in Toxoplasma pathogenesis.

In the next step of our study the concentrations of crucial protective cytokines in T. gondii infection, IFN- $\gamma$, IL-2 and IL-10, were quantified in the post-culture supernatants of the human PBMCs (Tables 4 and 5) and mouse splenocytes (Tables 6 and 7) infected with T. gondii (Tables 5 and 7 , respectively) or non-infected (Tables 4 and 6, respectively), and cultivated in the presence of phytoecdysteroids in the concentration range of $2-100 \mu \mathrm{g} / \mathrm{ml}$ (Tables 4, 5, 6 and 7). Treatment of human (Table 4) and mouse (Table 6) host cells with both tested ecdysteroids did not significantly change their secretory activity and the levels of IFN- $\gamma$ and IL-2 as well as IL-10 were similar in cultures supplemented with ecdysteroids as compared to adequate controls without the compounds. The same results were observed in human PBMCs (Table 5) and mouse splenocytes (Table 7 ) infected in vitro by $T$. gondii RH tachyzoites. The host status: infected (BALB/c mice) vs. noninfected (BALB/c and C57BL/6 mice) (Tables 6 and 7) and phytoecdysteroids responder (humans, group A) vs. nonresponder (humans, group B) (Table 4 and 5) did not appear to be important factors influencing cytokines secretion. But comparison of cytokine levels in control cultures of uninfected and not stimulated with phytoecdysteroids (Tables 4 and 6) vs. Toxoplasma infected and not stimulated with phytoecdysteroids host cells shows that $T$. gondii $\mathrm{RH}$ strain aroused IFN- $\gamma$ and IL-10 production (Tables 5 and 7). This result is consistent with another observation that in vitro infection with type I strain did not inhibit NF- $\kappa$ B p65 but activated c-Rel nuclear translocation [54], an important host additional signaling pathway in the regulation of inflammatory, immune, and antiapoptotic responses. The simultaneous presence of another stimulator such as phytoecdysteroids did not affect the cytokines release. According to our results presented in Tables 4, 5, 6 and 7, the tested phytoecdysteroids alone or in Toxoplasma co-cultures did not stimulate the in vitro secretion of the essential cytokines, either by human or by murine immune cells involved in an effective intracellular killing of the parasite. It is highly probable that, as in the case of HeLa [50], phytoecdysteroids inhibit NF- $\mathrm{KB}$ which is required for the production of cytokines such as IFN- $\gamma$ or IL-12 [59]. The observed lack of Toxoplasma proliferation in human PBMCs in the presence of ConA (Table 2) correlated with the lack of IL-10 production but concomitantly with a statistically significant increase in IFN- $\gamma$ level (Table 5). Interestingly, only in the phytoecdysteroids concentration of $20 \mu \mathrm{g} / \mathrm{mL}$ (Table 7), the levels of IFN- $\gamma$ in the cultures of $T$. gondii-infected spleen cells derived from $T$. gondii-negative BALB/c mice were significantly lower $(p<0.05)$ than in controls and in other test cultures supplemented with ecdysteroids. Lower levels of IFN- $\gamma$ were associated with higher parasite proliferation (Table 3).

\section{Conclusions}

Judging by the effect of phytoecdysteroids on the $T$. gondii proliferation, demonstrated for the first time in this study, it seems that these compounds should not be taken into consideration as potential medications to treat toxoplasmosis. Phytoecdysteroids included in the food are most likely not harmful for human or animal health but certain nutrients containing ecdysteroids at high concentrations could promote $T$. gondii proliferation in chronically infected and immunocompromised

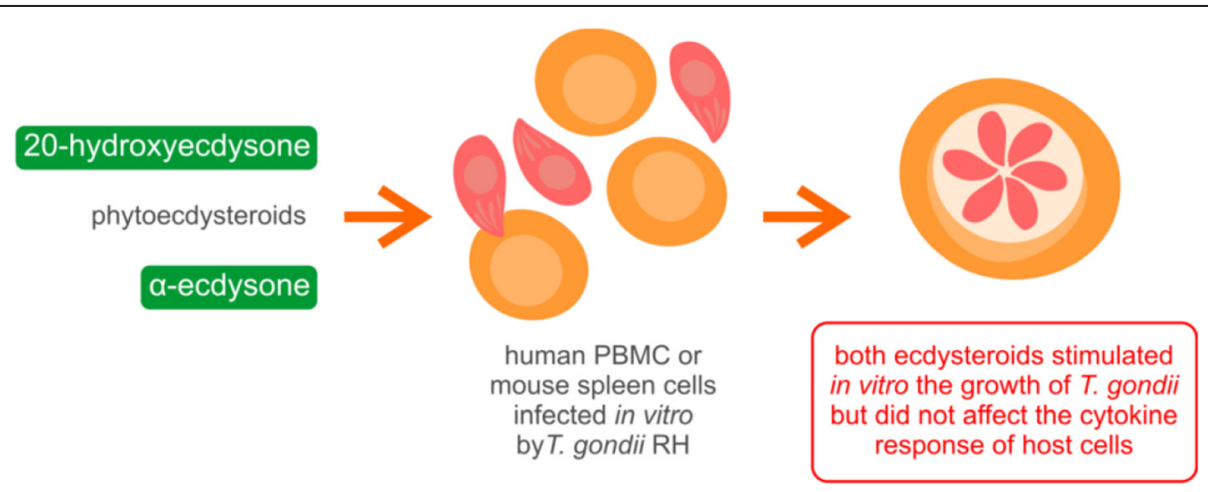

Fig. 3 Graphical Conclusions 
individuals. In order to assess the real impact of ecdysteroids on the course of natural $T$. gondii invasion, in vivo research should be undertaken because it cannot be ruled out that the in vivo effect will be different than the in vitro one. However, taking into account the possible stimulating effect of ecdysteroids on some opportunistic parasites (such as Toxoplasma or Strongyloides) further studies are necessary and should focus on the mechanisms of their action, which directly or indirectly enhance the parasite growth. Since ecdysteroids are considered as potential drugs, it is essential to determine their effect on various parasitic pathogens, which may infect the host at the same time, especially in immunocompromised individuals (Fig. 3).

\section{Competing interests}

The authors declare that they have no competing interests.

\section{Authors' contributions}

KD designed the study, performed the experimental work, analyzed the data and wrote the manuscript. MMG contributed to the experimental work and performed the statistical analysis. JP, BD and JG conducted the experiments. PS and HD revised the manuscript. All authors read and approved the final manuscript.

\section{Acknowledgements}

The project was funded by the National Science Centre (decision number: 2011/01/B/NZ6/01 880). We are thankful to Magdalena Antczak, M.Sc. for technical assistance.

\section{Author details}

'Department of Immunoparasitology, Faculty of Biology and Environmental Protection, University of Łódź, Banacha 12/16, 90-237 Łódź, Poland. ²Institute of Medical Biology of the Polish Academy of Sciences, Lodowa 106, 93-232 Łódź, Poland. ${ }^{3}$ Department of Microbial Genetics, Faculty of Biology and Environmental Protection, University of Łódź, Banacha 12/16, 90-237 Łódź, Poland.

Received: 13 December 2014 Accepted: 27 July 2015

Published online: 15 August 2015

\section{References}

1. Tenter AM, Heckeroth AR, Weiss LM. Toxoplasma gondii: from animals to humans. Int J Parasitol. 2000:30:1217-58

2. Alvarado-Esquivel C, Pacheco-Vega SJ, Hernández-Tinoco J, SánchezAnguiano LF, Berumen-Segovia LO, Rodríguez-Acevedo FJ, et al. Seroprevalence of Toxoplasma gondii infection and associated risk factors in Huicholes in Mexico. Parasit Vectors. 2014;7:301-8.

3. Dzitko K, Malicki S, Komorowski J. Effect of hyperprolactinaemia on Toxoplasma gondii prevalence in humans. Parasitol Res. 2008;102:723-9.

4. Dubremetz JF, Ferguson DJP. The role played by electron microscopy in advancing our understanding of Toxoplasma gondii and other apicomplexans. Int J Parasitol. 2009:39:883-93.

5. Torrey EF, Yolken RH. Toxoplasma gondii and schizophrenia. Emerg Infect Dis. 2003:9:1375-80.

6. Miman O, Kusbeci OY, Aktepe OC, Certinkaya Z. The probable relation between Toxoplasma gondii and Parkinson's disease. Neurosci Lett. 2010;475:129-31.

7. Stommel EW, Seguin R, Thadani VM, Schwartzman JD, Gilbert K, Ryan KA, et al. Cryptogenic epilepsy: an infectious etiology? Epilepsia. 2001;42:436-8.

8. Weiss LM, Dubey JP. Toxoplasmosis: A history of clinical observation. Int J Parasitol. 2009:39:895-901.

9. de Azevedo KML, Setubal S, Lopes VGS, Camacho LA, Oliveira SA. Congenital toxoplasmosis transmitted by human immunodeficiency-virus infected women. Braz J Infect Dis. 2010;14:186-9.
10. Petersen E, Schmidt DR. Sulfadiazine and pyrimethamine in the postnata treatment of congenital toxoplasmosis: what are the options? Expert Rev Anti Infect Ther. 2003;1:175-82.

11. Dibbern Jr DA, Montanaro A. Allergies to sulfonamide antibiotics and sulfur-containing drugs. Ann Allergy Asthma Immunol. 2008;100:91-100.

12. Dziadek B, Gatkowska J, Grzybowski M, Dziadek J, Dzitko K, Dlugonska H. Toxoplasma gondii: the vaccine potential of three trivalent antigen-cocktails composed of recombinant ROP2, ROP4, GRA4 and SAG1 proteins against chronic toxoplasmosis in BALB/C mice. Exp Parasitol. 2012;131:133-8.

13. Chuang S-C, Ko J-C, Chen C-P, Du J-T, Yang C-D. Induction of long-lasting protective immunity against Toxoplasma gondii in BALB/C mice by recombinant surface antigen 1 protein encapsulated in poly (lactide-co-glycolide) microparticles. Parasit Vectors. 2013;6:34.

14. Cong $\mathrm{H}$, Zhang $\mathrm{M}$, Xin $\mathrm{Q}$, Wang Z, Li Y, Zhao $\mathrm{Q}$, et al. Compound DNA vaccine encoding SAG1/ SAG3 with A2/B subunit of cholera toxin as a genetic adjuvant protects BALB/c mice against Toxoplasma gondii. Parasit Vectors. 2013;6:63.

15. Martins-Duarte ES, Urbina JA, de Souza W, Vommaro RC. Antiproliferative activities of two novel quinuclidine inhibitors against Toxoplasma gondii tachyzoites in vitro. J Antimicrob Chemother. 2006;58:59-65.

16. Dzitko K, Paneth A, Plech T, Pawełczyk J, Stączek P, Stefańska J, et al. 1,4-disubstituted thiosemicarbazide derivatives are potent inhibitors of Toxoplasma gondii proliferation. Molecules. 2014;19:9926-43.

17. Dzitko K, Paneth A, Plech T, Pawełczyk J, Weglinska L, Paneth P. Triazolebased compounds as the candidate to develop a novel medicines to treat toxoplasmosis. Antimicrob Agents Chemother. 2014;58:7583-5.

18. Asgari Q, Keshavarz H, Rezaeian M, Motazedian MH, Shojaee S, Mohebali M, et al. Direct effect of two naphthalene-sulfonyl-indole compounds on Toxoplasma gondii tachyzoite. J Parasitol Res. 2013;2013:1-8.

19. Bilia AR, de Malgalhaes PM, Bergonzi MC, Vincieri FF. Simultaneous analysis of artemisinin and flavonoids of several extracts of Artemisia annua $\mathrm{L}$. obtained from a commercial sample and a selected cultivar. Phytomedicine. 2006;13:487-93.

20. Jones-Brando L, D'Angelo L, Posner GH, Yolken R. In vitro inhibition of Toxoplasma gondii by four new derivatives of artemisinin. Antimicrob Agents Chemother. 2006;50:4206-8.

21. Dzitko K, Gatkowska J, Plocinski P, Dziadek B, Długońska H. The effect of prolactin (PRL) on the growth of Toxoplasma gondii tachyzoites in vitro. Parasitol Res. 2010;107:199-204.

22. Gueye PEO, Diallo M, Deme AB, Badiane AS, Dior DM, Ahouidi A, et al. Tea Artemisia annua inhibits Plasmodium falciparum isolates collected in Pikine, Senegal. Afr J Biochem Res. 2013;7:107-12.

23. Choi KM, Gang J, Yun J. Anti-Toxoplasma gondii RH strain activity of herbal extracts used in traditional medicine. Int J Antimicrob Agents. 2008;32:360-2.

24. Subeki MH, Matsuura H, Takahashi K, Yamasaki M, Yamato O, Maede Y, et al. Antibabesial activity of protoberberine alkaloids and 20hydroxyecdysone from Arcangelisia flava against Babesia gibsoni in culture. J Vet Med Sci. 2005;67:223-7.

25. Burg JL, Grover CM, Pouletty P, Boothroyd JC. Direct and sensitive detection of a pathogenic protozoan, Toxoplasma gondii, by polymerase chain reaction. J Clin Microbiol. 1989:27:1787-92.

26. Wahab T, Edvinsson B, Palm D, Lindh J. Comparison of the AF146527 and B1 repeated elements, two real-time PCR targets used for detection of Toxoplasma gondii. J Clin Microbiol. 2010;48:591-2.

27. Grigg ME, Sundar N. Sexual recombination punctuated by outbreaks and clonal expansions predicts Toxoplasma gondii population genetics. Int J Parasitol. 2009:39:925-33.

28. Dubey JP, Lindsay DS, Speer CA. Structures of Toxoplasma gondii tachyzoites, bradyzoites, and sporozoites and biology and development of tissue cysts. Clin Microbiol. 1998;11:267-99.

29. Lijnen P, Saavedra A, Petrov V. In vitro proliferative response of human peripheral blood mononuclear cells to concanavalin A. Clin Chim Acta. 1997;264:91-101.

30. Tomar A, Bansal MP, Ram GC. Maintenance of concanavalin A stimulated T lymphocytes from peripheral blood of goats. Small Rum Res. 1995;18:89-94.

31. Pfefferkorn ER, Pfefferkorn LC. Specific labeling of intracellular Toxoplasma gondii with uracil. J Protozool. 1977;24:449-53.

32. Meneceur P, Bouldouyre MA, Aubert D, Villena I, Menotti J, Sauvage V, et al. In vitro susceptibility of various genotypic strains of Toxoplasma gondii to pyrimethamine, sulfadiazine, and atovaquone. Antimicrob Agents Chemother. 2008;52:1269-77. 
33. Doliwa C, Escotte-Binet S, Aubert D, Velard F, Schmid A, Geers R, et al. Induction of sulfadiazine resistance in vitro in Toxoplasma gondii. Exp Parasitol. 2013;133:131-6.

34. De Oliveira TC, Silva DA, Rostkowska C, Béla SR, Ferro EA, Magalhães PM, et al. Toxoplasma gondii: Effects of Artemisia annua L. on susceptibility to infection in experimental models in vitro and in vivo. Exp Parasitol. 2009;122:233-41.

35. van der Ven AJ, Schoondermark-van de Ven EM, Camps W, Melchers WJ, Koopmans PP, van der Meer JW, et al. Anti-toxoplasma effect of pyrimethamine, trimethoprim and sulphonamides alone and in combination: implications for therapy. J Antimicrob Chemother. 1996:38:75-80.

36. Jin C, Jung SY, Kim SY, Song HO, Park H. Simple and efficient model systems of screening anti-Toxoplasma drugs in vitro. Expert Opin Drug Discovery. 2012;7:195-205

37. Cortez MR, Provençano A, Silva CE, Mello CB, Zimmermann LT, Schaub GA, et al. Trypanosoma cruzi: effects of azadirachtin and ecdysone on the dynamic development in Rhodnius prolixus larvae. Exp Parasitol. 2012;131:363-71.

38. Barker GC, Mercer JG, Rees HH, Howells RE. The effect of ecdysteroids on the microfilarial production of Brugia pahangi and the control of meiotic reinitiation in the oocytes of Dirofilaria immitis. Parasitol Res. 1991;77:65-71.

39. Townson S, Tagboto SK. In vitro cultivation and development of Onchocerca volvulus and Onchocerca lienalis microfilariae. Am J Trop Med Hyg. 1996:54:32-7.

40. Satoh M, Kiyuna S, Shiroma Y, Toma H, Kokaze A, Sato Y. Predictive markers for development of strongyloidiasis in patients infected with both Strongyloides stercoralis and HTLV-1. Clin Exp Immunol. 2003;133:391-6.

41. Siddiqui AA, Stanley CS, Skelly PJ, Berk SL. A cDNA encoding a nuclear hormone receptor of the steroid/thyroid hormone-receptor superfamily from the human parasitic nematode Strongyloides stercoralis. Parasitol Res. 2000;86:24-9.

42. Nisbet AJ, Cottee P, Gasser RB. Molecular biology of reproduction and development in parasitic nematodes: progress and opportunities. Int J Parasitol. 2004;34:125-38.

43. Báthori M, Tóth N, Hunyadi A, Márki A, Zador E. Phytoecdysteroids and anabolic-androgenic steroids structure and effects on humans. Curr Med Chem. 2008;15:75-91.

44. Sláma K, Koudela K, Tenora J, Mathova A. Insect hormones in vertebrates: anabolic effects of 20-hydroxyecdysone in Japanese quails. Experientia. 1996:52:702-6.

45. Kratky F, Opletal L, Hejhalek J, Kucharova S. Effect of 20-hydroxyecdysone on the protein synthesis of pigs. Zivocisna Vyroba. 1997;42:445-51.

46. Trenin DS, Volodin W. 20-hydroxyecdysone as a human lymphocyte and neutrophil modulator: In vitro evaluation. Arch Insect Biochem Physiol. 1999:41:156-61.

47. Hung TJ, Chen WM, Liu SF, Liao TN, Lee TC, Chuang LY, et al. 20 -Hydroxyecdysone attenuates TGF- $\beta 1$-induced renal cellular fibrosis in proximal tubule cells. J Diabetes Complications. 2012;26:463-9.

48. Harmatha J, Vokác K, Kmonícková E, Zídek Z. Lack of interference of common phytoecdysteroids with production of nitric oxide by immune-activated mammalian macrophages. Steroids. 2008;73:466-71.

49. Taniguchi SF, Bersani-Amado CA, Sudo LS, Assef SMC, Oga S. Effect of Pfaffia iresinoides on the experimental inflammatory process in rats. Phytother Res. 1997;11:568-71.

50. Peschel W, Kump A, Prieto JM. Effects of 20-hydroxyecdysone, Leuzea carthamoides extracts, dexamethasone and their combinations on the NF-KB activation in HeLa cells. J Pharm Pharmacol. 2011;63:1483-95.

51. Kim JM, Oh YK, Kim YJ, Cho SJ, Ahn MH, Cho YJ. Nuclear factor-kappa B plays a major role in the regulation of chemokine expression of HeLa cells in response to Toxoplasma gondii infection. Parasitol Res. 2001;87:758-63.

52. Du J, An R, Chen L, Shen $Y$, Chen $Y$, Cheng $L$, et al. Toxoplasma gondii virulence factor ROP18 inhibits the host NF-kB pathway by promoting p65 degradation. J Biol Chem. 2014;289:12578-92.

53. Shapira S, Speirs K, Gerstein A, Caamano J, Hunter CA. Suppression of NFkappaB activation by infection with Toxoplasma gondii. J Infect Dis. 2002;185 Suppl 1:S66-72.
54. Rosowski EE, Lu D, Julien L, Rodda L, Gaiser RA, Jensen KD, et al. Strain-specific activation of the NF-kappaB pathway by GRA15, a novel Toxoplasma gondii dense granule protein. J Exp Med. 2011;208:195-212.

55. Molestina RE, Payne TM, Coppens I, Sinai AP. Activation of NF-kappaB by Toxoplasma gondii correlates with increased expression of antiapoptotic genes and localization of phosphorylated IkappaB to the parasitophorous vacuole membrane. J Cell Sci. 2003;116:4359-71.

56. Payne TM, Molestina RE, Sinai AP. Inhibition of caspase activation and a requirement for NF-kappaB function in the Toxoplasma gondii-mediated blockade of host apoptosis. J Cell Sci. 2003;116:4345-58.

57. Molestina RE, Sinai AP. Host and parasite-derived IKK activities direct distinct temporal phases of NF-kappaB activation and target gene expression following Toxoplasma gondii infection. J Cell Sci. 2005;118:5785-96.

58. Butcher BA, Kim L, Johnson PF, Denkers EY. Toxoplasma gondii tachyzoites inhibit proinflammatory cytokine induction in infected macrophages by preventing nuclear translocation of the transcription factor NF-kappa B. J Immunol. 2001;167:2193-201.

59. Caamaño J, Alexander J, Craig L, Bravo R, Hunter CA. The NF-kappa B family member RelB is required for innate and adaptive immunity to Toxoplasma gondii. J Immunol. 1999;163:4453-61.

\section{Submit your next manuscript to BioMed Central and take full advantage of:}

- Convenient online submission

- Thorough peer review

- No space constraints or color figure charges

- Immediate publication on acceptance

- Inclusion in PubMed, CAS, Scopus and Google Scholar

- Research which is freely available for redistribution 